\title{
Roger Gilbert
}

\section{Ruth Stone’s Intricate Simplicities}

RUTH STONE'S Simplicity is the kind of book one might expect from a great poet just hitting her stride, eagerly testing the full range of her powers for the first time. Its 116 pages-unusually generous for a book of poems these days-embrace a dazzling array of genres, styles, forms, while the poems themselves touch every conceivable tone of feeling from grief to fury, ribaldry to tenderness. All this expansive energy may be misleading, however: Ruth Stone turned eighty last year. Only a very few poets have written at their peak this late in their careers. Yeats is the preeminent example in English; Hardy, Stevens, perhaps Williams could be named as well. Yet their late poetry, powerful as it is, reflects a contracting of sensiblity, a detachment from worldly concerns, that might seem inevitable in old age. (An obituary quoted Stephen Spender saying, apropos of age, "I enjoy being slightly withdrawn from everything, looking at things more from the outside.") What is most remarkable about the poems in Simplicity is their boisterous and passionate engagement with the world in all its tangles of nature and culture, fact and fiction, eros and violence.

Before I discuss these extraordinary poems in detail, I must address the riddle of Stone's relative obscurity. "Relative" is an important qualifier, for Stone has in fact long enjoyed a devoted following that includes some of our best-known poets and critics. John Ashbery, Donald Hall, Richard Wilbur, Leslie Fiedler, Sharon Olds, and Lucille Clifton are among those who have sung her praises, and this year a book of essays on her work was published entitled The House Is Made of Poetry: The Art of Ruth Stone. Yet she can hardly be called a "poet's poet," if that term implies a writer best appreciated by insiders; Stone is one of the most accessible poets alive, and her poems provide a kind of immediate pleasure, both on the page and in her incomparable readings, that one seldom finds in contemporary poetry. The short answer to the question of why she isn't better known may be that she's resolutely kept her distance from the various Po Biz circuits that manufacture

Simplicity by Ruth Stone. Paris Press, 1995. 116 pages, $\$ 12.95$ paper. 
reputations today. Though she's taught creative writing at many universities over the years, she's never been fully connected to the MFA network, nor has she associated herself with any recognized schools or movements. (Stone has written some wickedly funny poems lambasting the contemporary poetry scene and its assembly-line products, including "Some Things You'll Need to Know Before You Join the Union" and "Flash," the latter in Simplicity.) Although her first three books were brought out by Harcourt Brace Jovanovich, for the past twenty years she's chosen to publish with small presses like Yellow Moon and Paris Press. In short Stone possesses little knack for self-promotion, and has therefore spent most of her poetic life engaged in that least lucrative of tasks, writing poems.

Another reason Stone remains comparatively unknown is that her career has not followed the usual chronological pattern. A perennial late starter, she published her first book at forty-four. In this respect she follows a grand American tradition that includes Whitman and Stevens, who both published first books in their late thirties (though she can't match Amy Clampitt, whose first book appeared when she was in her sixties). Having missed out on her chance to be hailed as a rising young poet, Stone contented herself with a steady though intermittent output of volumes, each of which garnered quiet praise: In an Iridescent Time (1959), Topography (1970), Cheap (1975), Second-Hand Coat (1987), Who Is the Widow's Muse (1991), and now Simplicity, along with assorted chapbooks. But perhaps the most spectacular instance of Stone's penchant for lateness was her appointment at the age of seventy-five to her first tenured position, in SUNY Binghamton's English department. The freshness and vitality of her recent work may well owe something to her disregard for established timetables; one of the few surviving members of a troubled poetic generation that included Lowell, Bishop, Berryman, Jarrell and Olson, Stone at eighty is anything but burned out. On the contrary, she still gives the impression of starting from scratch, discovering the resources of poetry with amazed delight.

But it would do Stone a disservice to harp too peevishly on her neglect, frustrating though it is to her admirers. As Willis Barnstone eloquently puts it (after calling Stone "America's Akhmatova" and "the secret great poet of the English language"): "Let's not worry why at 
eighty she isn't immediately known as our living Eliot, Stevens, or Bishop. Rather let us atone by reading, hearing, and absorbing the iridescence of her poems in Simplicity." As I've suggested, those poems are striking above all for their virtuoso range of subject, tone and technique. Nothing lies outside Stone's field of vision; she writes with equal passion of politics and sex, science and art, trees and trailers, while her voice glides with the fluidity of Sarah Vaughan from the darkest to the brightest of timbres and back, sometimes in the course of a few words. This capacity for swift modulation can occasionally be disorienting, especially since Stone seems to eschew any clear organizing pattern for the collection as a whole. Unlike some of her previous books, Simplicity is not divided into sections or groups of poems, either formal or implicit. Instead poems with similar themes and qualities are scattered throughout, as though to mimic the random variegations of experience.

This is clearest in her tendency to juxtapose deeply serious poems and playful folderols. Thus "Coffee and Sweet Rolls," one of the book's many elegies for Stone's husband (who died when she was forty-three), ends with a movingly erotic reminiscence of "you standing thin and naked, / the shy flush of your rising cock pointed toward heaven, / as you pull down the dark window shade," and is immediately followed by a much daffier poem called "The Solution," in which the poet hears her "friend the Supermarket" exhorting her to "Have an electric clock and a big cucumber. / Very cheap. / You can set yourself to go off with the alarm." Sex as lost love and as mechanized consumption: the transition is daring, in part because it risks destroying the tender nostalgia summoned by the first poem. Yet Stone is willing to sacrifice the autonomy of her poetic moods for the sake of that larger sense of exhilarating breadth her book both celebrates and embodies. Blurring accepted boundaries between earnest and playful speech, high emotion and low comedy, Stone keeps reminding us that the world is all of a piece; there are no signposts to tell us when to laugh and when to cry.

Laughter is assuredly a basic ingredient in this book, as it has been in all Stone's poetry. Some of the poems in Simplicity first appeared in a chapbook entitled Nursery Rhymes from Mother Stone-a nom de plume the poet reserves for her lightest verse, poetic doodles and bagatelles 
that provide a kind of leavening for her weightier efforts. Typically quite short and loaded with puns, these "Mother Stone" poems are not labelled or segregated but simply crop up unexpectedly in the midst of more sombre pieces. Again this seems to be a deliberate strategy on Stone's part, her way of insisting on the continuities between play and contemplation. "Lullaby" conveys the general flavor of these poems:

New Wave babies

kiss their computers.

Good night Orno and Porno.

They put on their Hug-Me-Tites.

Pucker and poo.

Program the buttons.

Karoom! Kaboom!

$\mathrm{E}=\mathrm{m} \mathrm{c}^{2}$

So long. Toodle-oo.

Techspeak meets baby talk. For all its patent silliness, the poem's crib'seye view of apocalypse links it to some of the more ambitious pieces in Simplicity, which take a colder look at earth's imminent destruction. Even in her most frivolous moods, Mother Stone keeps the shadow of disaster in sight.

Another set of poems wryly brood over the mind/body problem as exacerbated by age. Less downright goofy than the Mother Stone rhymes, these nonetheless display a certain rueful wit, as in "Metamorphosis":

One day you wake up and you have a new face.

What's this? you say

in the harsh kosher manner

of your mother-in-law in a high-class restaurant.

Although your hair is Titian red and not blue rinse like hers, she always sent whatever it was backNo matter how many times you look in the mirror you can't make it go away. [...] 
The poem rings an ingenious variation on the old cliché that women turn into their mothers; this speaker instead becomes her mother-inlaw, not because age has made their faces similar but because she adopts the older woman's attitude of curdled disgust toward what time has served up. A lovely poem called "The Cord" offers a less antagonistic account of body/mind relations:

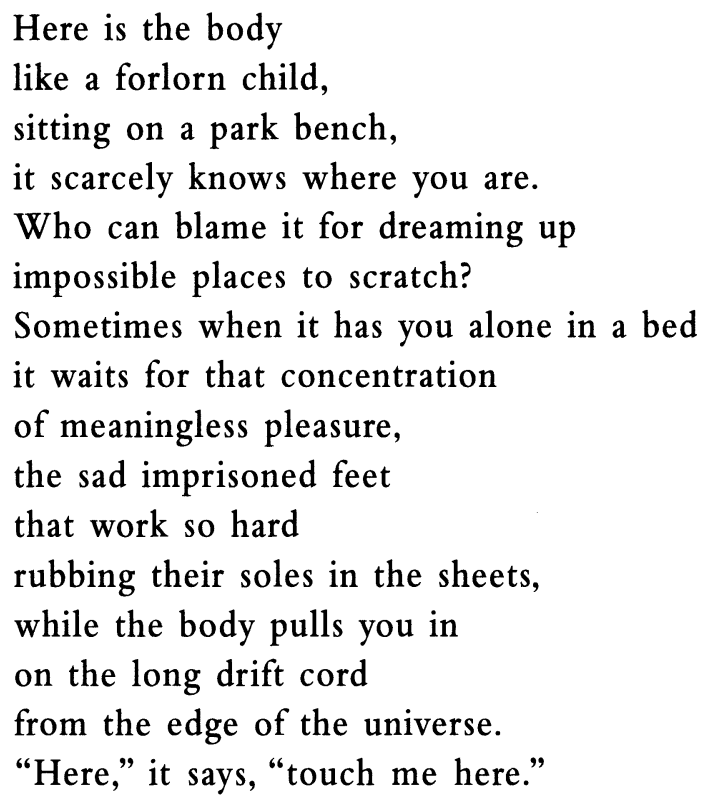

The poem makes us laugh in recognizing the chasm between the mind's vague drifting and the flesh's utterly specific demands; but there's a strange pathos, too, in its portrayal of the body as a "forlorn child," forever trying to get the attention of a distracted grown-up.

Stone's wit extends to her handling of poetic form, though here too play remains in uneasy equlibrium with urgency. An example is a tourde-force entitled "A Very Stretched Sennett":

Some things like the fat policeman and the black prostitute aren't fit for sonnets. But the form for today is fourteen lines iambic pentameter. Won't compute. Maybe by cheating a little I can get away with passing this off. Think of a Mack Sennett 
comedy in black and white, say Oliver Hardy is the cop. He's dragging the would-be tenant of the bus station, a skinny black party girl. She's screaming, dress up to her crotch. His arms are holding her. It's very sexual.

They go the length of the station. Her charms are obvious. He loves it. He's got her flesh. We all want to applaud. Finally he throws her out the door. We yawn. Now he's center front, rubbing his hands, smiling. Then she's back inside and he's chasing her again and so on.

Stone's point of departure in this poem is the odd homology of "sonnet" and "Sennett," two genres seemingly light years apart in tone and substance yet possessed of a similar classicism of form-just as all sonnets obey the same prosodic pattern, so all Mack Sennett comedies follow the same rough outline, complete with obligatory chase scene. What makes Stone's pairing of these two forms more than a mere exercise in incongruity is her application of them to a scene whose raw brutality just filters through the double lens. The poem's opening lines suggest that the policeman and prostitute serve as a factual germ or donnée that resists the conventionalized rhetoric of the sonnet; Mack Sennett thus supplies a counter-form, permitting Stone to approach her subject through a different set of conventions. It's in the interstices between these clashing conventions that we glimpse the cycle of sadism and despair driving the narrative. As its title implies, the poem enacts a "stretching" of received form to accommodate social realitymost spectacularly in the closing line, with its Ogden Nashian elongation.

Stone performs a similar trick in a poem called "As I Remember," which uses the intricate villanelle form to recount the story of a $\mathrm{Ku}$ Klux Klan leader's secretary found dead in his hotel room, then departs from the form entirely in the last three lines, as if to show its inadequacy to wholly contain the sordid facts. In these poems violence gets processed by formal convention, so that we feel the tension between fact and representation as a kind of muffling which paradoxically makes a human tragedy more present. One of Stone's constant preoccupations is with the way our culture packages and obscures the 
reality of suffering; her task as poet is to push beyond the neutralizing mask and expose the irreducible, bodily truth it hides. Her poem "The News" is a masterpiece in this mode:

What have you to say to that contorted gunned-down pile of rags in a road; possibly nameless even to the one who throws it on a cart and pushes it away?

The discarded New York Times is wrapped around your garbage, a now wet, on-the-scene still from someone's news camera, stained with scraps from your kitchen.

And whose illusion that woman running with a child? Already struck, the machine gun crossing the line of her body yet she does not fall although she is already dead-

her history written backwardThere is no time to weep for her. This was once the snot of semen, the dim blue globe of the egg moving through the fallopian tube.

That single body casting itself into the future.

Most poets would try to bring us closer to the woman in the news photo by imagining her agony as bullets shatter her body; a few might try to picture her as a child, before violence found her. Only Stone, I think, could have conceived this way of making the woman real, avoiding both the sensational and the sentimental by tracing her history all the way back to its originary moment in the womb. Poems like this show Stone to be a political poet in the fullest and deepest sense, concerned not merely with local conflicts but with what might be called the epis- 
temology of compassion - that imaginative power to know and acknowledge the other upon which all political engagement depends.

The challenge of otherness in all its forms lies at the heart of Stone's poetry. Many of her poems chart a process of inference that starts from some immediate scrap of evidence and moves toward the reconstruction of a life, a self. A poem titled simply "Other" begins "Why am I not that brown-skinned man / who passes my train window?" then goes on to fill in, with great tact and delicacy, a few purely conjectural details: "his own familiar legs, like mine, / not firm as they once were, / sometimes cramping at night." Stone is fully aware of the risks this kind of inferential imagining carries, above all the risk of presuming to know the other too well; a few lines later she reminds herself "I will never know who puts their arms / around him, if they do, / or who hands him his junk mail / in a men's only hotel." In this as in other poems she strikes a tenuous balance between imagining and refusing to imagine-note, for example, that while she won't speculate about the man's lover she does place him with quiet confidence in a men's only hotel. Stone understands that too scrupulously respecting the other's mystery can be as dangerous as aggressively classifying him; we must be willing to imagine other lives if we're to make them matter to us.

Like "Other," many of Stone's poems are set on trains and buses (or in train and bus stations). In the most literal sense this propensity can be traced to her chronic distrust of air travel; but it also facilitates the special relation to strangers that so much of her poetry explores. Not only do trains and buses bring her in contact with a different socioeconomic class of people than planes would, they make possible a different kind of encounter, less briskly purposeful, more lingering and contemplative. Poems like "Nuns at Lunch on the Bus," "Ritual," "Good Friday on the Bus," "The Real Southwest by Greyhound," and "Columbus, Ohio" record variously funny and painful incidents in which other people's inner lives fleetingly appear to the poet's voyeuristic gaze. Sometimes Stone's interest in the minute particulars of these other lives leads her in the direction of dramatic monologue, as in the hilarious "Sleeping Beauty IV" (there is no "Sleeping Beauty I," "II," or "III," a typically sly joke), which faithfully transcribes the rambling speech of a teenage girl exasperated with her newly divorced mom's 
tribulations. At other times she offers a more generic portrait of some marginal populace, as in "Living Space," a haunting evocation of trailer parks and their denizens.

But Stone's appetite for otherness is not confined to the human realm. A number of her poems fall into the category of dinggedichte or thing poems: poems that meditate on inanimate objects, trying, in Wordsworth's phrase, to "see into the life of things." Sometimes that life is mediated by death; "The System" broods over the slow transfiguration of a dead mole, while "As Miracles Go" discovers a similar alchemy in a more domestic setting:

\author{
While I was gone \\ the invisible alchemist \\ who lives in my house when I'm away \\ was still trying to make gold \\ out of nail clippings, \\ baking soda and llama fuzz. \\ What a fool! \\ This time I returned to a carafe of five \\ gelatinous purple-skinned mice, \\ drowned and bloated in the leftover coffee, \\ the plastic lid snapped down on the carafe. \\ They float in a circle as if they are \\ chasing each other nose to tail. \\ How long they have looked with insane hope, \\ their pink eyes staring out of this glass wall \\ at the wavering kitchen; \\ the pale spread pads of their feet \\ suppliant as the hands of novitiates.
}

As sheer description this poem is, I think, spectacularly successful; "gelatinous," for example, is a surprising but creepily evocative word that give the mice a tactile immediacy. What makes the poem so affecting, though, is the sudden shift of perspective that carries us inside the coffee pot, peering out with the drowning mice at "the wavering kitchen." In other poems Stone explores what academics like to call the "subject position" of trees, birds, hardware, spermatazoa, and even 
subatomic particles, as if to show that her powers of identification have no limit.

Stone's enormous capacity for giving voice to the invisible, the absent, and the inanimate may ultimately stem from the central place of bereavement in her poetry. As I've mentioned, her husband died in 1958 , and her poems have been returning to this loss ever since. When Stone addresses a "you" in her work it's usually her husband; many of the most poignant poems in Simplicity are elegies that take the form of conversations. A poem called "Talking to the Dead" explicitly meditates on this ghostly dialogue:

My talk to you, a continuous invention, like a sailor's tatting;

the casual thread between fingers becoming medallions.

Far back in the sailor's nebula of neurons, the delicate spread of lace.

Hooking this word to this word, my talk with you is a slip-stitch, a French-knot; embroidery over the plain cloth of waking and sleeping.

Upstairs in the back room, my unfinished appliqué quilt, folded away year after year, with the same last stitch and the same motionless needle.

My talk with you is not like the red-wing or nuthatch, not so practical now.

More like the snowmelt that cannot be stopped.

Cold and liquid, its crystals shattered, 
its pendulous breasts and testicles

rotting together;

the sweat of the snow

without muscle or will,

the plaything of gravity

says what I say to you:

the babble of nothing to nothing.

Stone's work of the last thirty-five years affords perhaps the fullest and most moving anatomy of widowhood to be found in our literature, and culminates in her recent book-length sequence Who Is the Widow's Muse? "Talking to the Dead" offers another of her many insights into the condition of survival. Its brilliant series of metaphors shifts from deliberate acts like tatting and embroidery to a purely involuntary process, the melting of snow, as though to empty the widow's talk of all meaning and intention. But even as she strips this speech of its communicative power, reducing it to "the babble of nothing to nothing," Stone refuses to abandon it altogether; the poem itself, after all, is an instance of its own subject, as the use of the second person makes clear. She will go on talking to the dead, while conceding that such talk may be no more than a reflex of grieving.

One phrase in this poem calls for special attention, since it points to a persistent feature of Stone's work: "the sailor's nebula of neurons," at once euphonious in its sound patterning and visionary in its conjunction of vast and microscopic realms, reveals her deep fascination with science in all its branches, from cosmology to biochemistry and particle physics. Like A. R. Ammons and Alice Fulton, Stone sees no schism between the languages of science and poetry. At times playful in her deployment of scientific concepts, at other times deadly serious, she writes many poems on such themes, including "The Sad Voice of the Hubble," spoken in the person of the orbiting telescope, and "Love and Money," which traces a photon's chemical progress up the molecular chain from sugar to starch to chlorophyll, and ends "I'm going to the top. / I'm going to make that green stuff." "Things I Say to Myself While Hanging Laundry" starts from the poet's observation of ants marching across a clothesline, then veers into a wild reverie that mixes 
entomology with Einsteinian physics. But even poems not centrally concerned with science find ways to smuggle its notions into their field. An especially fine example occurs in "Leaving New York with Harry," another poem addressed to her dead husband, which closes with this vivid reminiscence of their lovemaking:

as if we had been stitched together

by a surgeon at all our openings-

as if we lay inside one another

as in a Klein bottle,

the stamp of extermination on our foreheads.

Closely related to the Mobius strip, a Klein bottle is a vessel made up of a single continuous surface, with no clear division between inside and outside. An inspired trope for sexual passion, it transforms the more ghoulish image of stitched openings into an emblem of seamless coextension.

But while Stone's work draws on science with great authority, her first commitment is necessarily to art, and several of her poems meditate profoundly on the status of aesthetic objects like paintings and sculpture. Of these the most ambitious-indeed at seven pages the book's longest poem-is called "Medium for Stasis." An extraordinarily rich and nuanced study of a shabby apartment, its Russian emigrée inhabitants, and the various graphic media with which they might be rendered, it makes a worthy addition to the distinguished line of ecphrastic poetry that runs from Keats's "Ode on a Grecian Urn" through Bishop's "Large Bad Picture" and Ashbery's "Self-Portrait in a Convex Mirror." Like those poems, "Medium for Stasis" shifts its attention unpredictably between surface and depth, the represented scene and the means of representation. Thus Stone's patient analysis of the complex dynamics among Igor, an artist, Yasha, a chessplayer, and Igor's unnamed girlfriend is interspersed with passing comments on artistic methods ("Watercolor would do as a medium, / even a fauve technique, a quick catch"). The poem ends with an aphoristic pronouncement that illuminates both the imagined painting and the situation of its subjects: "A work of art / is a possible stasis where nothing is happening. / Where the energy of what has happened / stops at the moment of what will 
happen." If the poem defines an aesthetic, it's one that insists on the reciprocity of art and life, the futility of trying to separate medium from model.

The poetic medium traditionally attains its purest state in the lyric. Scattered among the narratives, elegies, travel poems, nursery rhymes, and monologues of Simplicity are a handful of poems that directly partake of the condition named by the title. Spare in form, quiet in diction, these poems display Stone's art at its most essential. Among them are the book's title poem, "Simplicity," a limpid account of fetching creek water in winter (something Stone has been doing for years at her rural Vermont home). Even more beautiful to my mind is a poem called "To My Dead Red-Haired Mother," which has the condensed, lapidary power achieved only by the highest art:

I loved a red-haired girl.

Freud knew it was a wicked thing to do.

This is how all poems begin.

Sometime after the age of two

I beat the Adam in me black and blue.

Infant, wicked infant!

I threw my love outside

and grew into a bride.

You and I reflecting in our bones

the sea and sky,

we dressed ourselves as flesh,

we learned to lie.

Dearly beloved,

forgive me for that mean and meager self,

that now would mingle

but must first die.

Everything contributes here, right down to the irregular rhyming, which is never obtrusive but subtly shapes the poem from beginning to end. (Like most poets of her generation-and unlike the so-called New Formalists-Stone was weaned on rhyme and knows how to use it dis- 
creetly, sometimes almost invisibly, so that it melts into the larger effects of the poem.) The placement of "red-haired" in the title and first line is an especially fine touch, both in its particularizing of what might otherwise seem too abstractly universal, and because it allows Stone to avoid the word "mother" in the poem itself, letting us infer that the "red-haired girl" of the first line is the mother of the title-an elision that in turn enhances the mood of labelless intimacy the poem so movingly evokes. As much as this lyric clearly owes to psychoanalytic theories of individuation and sexuality, it moves beyond them in its last two stanzas, which return to the ancient motif of death-as-mother with a clarity and directness one would hardly hope to find in a poem of the $90 \mathrm{~s}$. But Stone is able to sound this classical cadence largely thanks to the revisionary pressures, both psychoanalytic and feminist, that she brings to bear on a timeless theme. The poem differs enough from its canonical predecessors to establish itself as a genuinely new utterance, yet doesn't shy away from the kind of universalizing language we associate with older poets like Yeats and Dickinson. Its success owes much, of course, to more specific effects as well; note, for example, how Stone rejects the option of an easy syntactic and rhythmic parallel in the last two lines ("that now would mingle / but first must die") in favor of a more emphatic dissymmetry that grimly hammers the poem shut ("but must first die").

This poem and a few others in Simplicity are, I'm tempted to say, genuinely great works, poems that will likely survive for centuries. In saying this, however, I don't want to imply that they should be detached from the collection or weighed against its other poems. Ruth Stone is the kind of poet who seems able to write her best poems because she writes all of her poems; her work depends on a continuum between the most individually memorable poems and what may seem more casual efforts. In discussing this book I've tried to touch on its major themes and genres, but even a fairly long review can't do full justice to such scope and variety-I haven't, for instance, found a way to talk about "Scheherezade Is Mailed and Nailed in Five Days," a bizarre, apocalyptic fantasia on the Gulf War that demands numerous readings to make sense of. The book's title may seem to belie this restless range and diversity, but given Stone's interest in science it is perhaps justified to interpret "simplicity" in the specifically chemical 
sense: "Having or composed of one thing or part only; not combined or compound." All things, present and absent, real and imagined, partake of a single substance in Stone's metaphysics, and this applies equally to her own poems. But simplicity doesn't mean sameness, for within this substance are contained all the variegations of emotion and matter, time and space, form and spirit. In a wryly self-mocking poem called "Rotten Sample," Stone describes her life as a wandering peddler of poetry: "I travel like a salesman with my samples. / A little of this and that, / a ghostly other-than. . . ." Stone's poems offer samples, no two alike, of the turbulent simplicity we all inhabit. 